\title{
HILGARDIA
}

A Journal of Agricultural Science Published by the California Agricultural Experiment Station

RELATION OF TEMPERATURE

TO INFECTION OF BEAN AND

COWPEA SEEDLINGS BY

RHIZOCTONIA BATATICOLA

C. M. TOMPKINS and M. W. GARDNER

\section{THE OLIVE KNOT DISEASE: ITS INCEPTION, DEVELOPMENT, AND CONTROL}

EDWARD E.WILSON 


\section{$\begin{array}{lllllllll}H & \text { I } & \text { L } & G & A & R & D & \text { I } & A\end{array}$}

A Journal of Agricultural Science Published by

the California Agricultural Experiment Station

VoL. 9

FEBRUARY, 1935

No. 4

\section{RELATION OF TEMPERATURE TO INFECTION OF BEAN AND COWPEA SEEDLINGS BY RHIZOCTONIA BATATICOLA ${ }^{1}$}

C. M. TOMPKINS ${ }^{2}$ AND M. W. GARDNER ${ }^{3}$

KENDRICK ${ }^{(6)}$ HAS DESCRIBED a serious seedling blight of beans (Phaseolus vulgaris $\mathrm{L}$.) occurring in the Sacramento Valley and delta region, caused by the fungus, Rhizoctonia bataticola (Taub.) Butler. He showed that the disease was favored by high temperatures during the period of seedling emergence and observed that cowpeas (Vigna sinensis L.) under similar conditions appeared to escape infection. In order to learn more about the temperature relations, the mode of infection, and the apparent resistance of cowpeas, cultures of Rhizoctonia bataticola (Taub.) Butler isolated from various hosts have been compared as to cultural characters and effect of temperature on growth and pathogenicity to bean and cowpea seedlings.

\section{SOURCES OF CULTURES}

The cultures of Rhizoctonia bataticola from beet were isolated from a root-rot of sugar beet-A, B, and C, from beets collected near Walnut Grove, California; D and E near Marysville; and F near Stockton. The cultures from bean (A, B, C) were isolated by J. B. Kendrick from bean seedlings- $A$ and $B$ at Davis, $C$ near Lodi. The culture from cowpea was isolated from herbarium specimens of older diseased Blackeye cowpea plants collected at Modesto, California, by W. W. Mackie. The two cultures from sweet potato were isolated from a rot of sweet potatoes near Atwater, California. The culture from begonia was supplied by M. R. Harris of the California State Department of Agriculture. The culture from citrus was supplied by H. S. Fawcett, Riverside. The

1 Received for publication August 16, 1934.

2 Assistant Plant Pathologist in the Experiment Station.

3 Professor of Plant Pathology and Pathologist in the Experiment Station. 
culture from strawberry was isolated by W. C. Snyder from strawberry roots from Santa Cruz, and the culture from cotton was by Snyder from specimens sent from Texas by J. J. Taubenhaus. Haigh's A, B, and C cultures were kindly sent to Kendrick by J. C. Haigh. Culture A was from Acacia in Kenya, B from hibiscus in Ceylon, and C from Juniperus in Ceylon. A culture of Rhizoctonia solani isolated by L. D. Leach from dry rot of sugar beet at Davis, was also used.

\section{MORPHOLOGICAL AND CULTURAL CHARACTERS OF THE CULTURES USED}

In an attempt to bring about the production of pycnidia, all except the culture from cowpea were grown on sterilized beet plugs, potato plugs, and bean pods at $28^{\circ}, 31^{\circ}$, and $34^{\circ} \mathrm{C}$ for a month and then at room temperatures until dried out, but no pycnidia were produced; nor were they produced in cultures on Leonian's agar, ${ }^{(7)}$ Coon's agar, ${ }^{(3)}$ Brown's asparagin agar, ${ }^{(2)}$ Dox's agar as used by Haigh, ${ }^{(4)}$ cornmeal agar, or prune agar.

No two of the cultures were alike in cultural characters even though six were from sugar-beet roots, three from bean seedlings, and two from sweet potatoes. The cultures were grown on cornmeal agar, potato dextrose agar, prune agar, and Dox's agar in petri plates at $28^{\circ} \mathrm{C}$ and compared at the end of four days as to color and type of mycelium and abundance of sclerotia, but no grouping was possible. The mycelial differences in seven of the cultures grown on prune agar for two days at $28^{\circ} \mathrm{C}$ are shown in figure 1 . With all of the cultures, potato dextrose agar was most favorable and Dox's agar was least favorable for the production of sclerotia.

The cultures were compared as to chromogenesis in tube cultures on Brown's asparagin agar, Coon's agar, Leonian's agar, and potato dextrose agar at the end of two months. In general, there was no discoloration of the agar. However, in Brown's asparagin agar, Haigh's A strain produced a light brown color; and a pinkish color was produced by the $B$ culture from bean and the cultures from strawberry in all of the media, by the B culture from beet in all except Leonian's agar, by the D culture from bean in Leonian's agar and by the culture from cotton in Leonian's and potato dextrose agar.

All of the cultures with the exception of Haigh's A and B strains, which have large sclerotia, were compared as to size of sclerotia in cultures grown 14 days at $28^{\circ} \mathrm{C}$ on potato dextrose agar of $\mathrm{pH} 5.6$. One hundred sclerotia of each culture were measured and the mean diameters in microns were as follows : Beet A, 81.9; beet $\mathrm{B}, 83.8$; beet $\mathrm{C}, 73.8$; beet D, 86.8; beet E, 86.8; beet F, 87.2; bean A, 81.9; bean B, 75.4; bean C, 
109.7; cowpea, 121.6; sweet potato A, 129.8; sweet potato B, 125.1; begonia, 108.9; citrus 66.2 ; strawberry, 110.1; cotton, 71.9; Haigh C, 68.7.

All except the cultures from sweet potato and cowpea fall within the limits of Haigh's C group, in which the diameter of the sclerotia is $120 \mu$ or less, and, according to the work of Ashby ${ }^{(1)}$ and Haigh, ${ }^{(4)}$ should be designated as Macrophomina phaseoli (Maubl.) Ashby. The sclerotia of

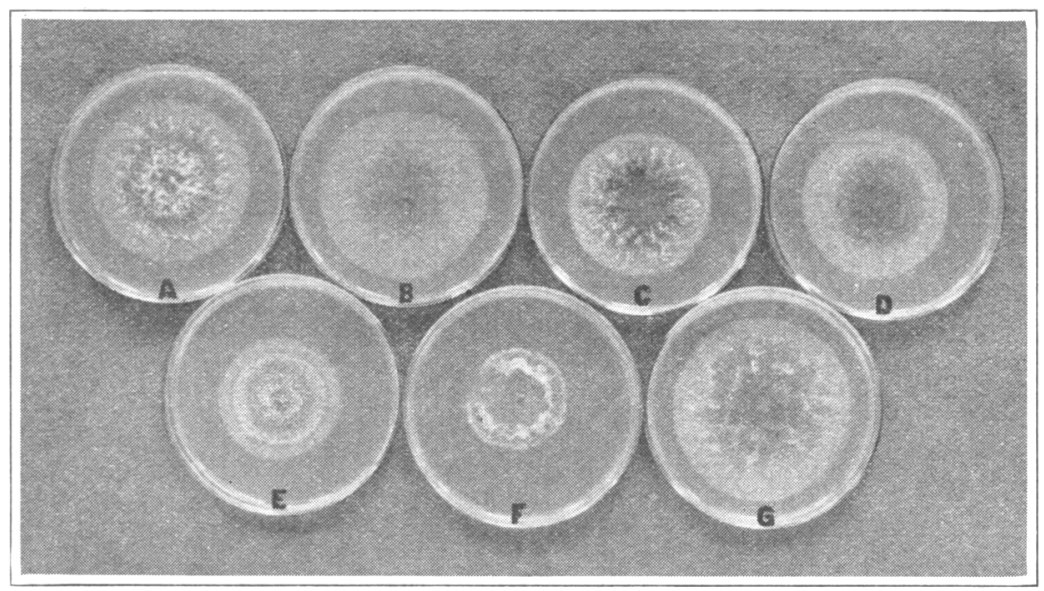

Fig. 1.-Differences in the mycelium of cultures of Rhizoctonia bataticola; 2-day old colonies on prune agar, $\mathrm{pH} 5.6$, at $28^{\circ} \mathrm{C}: A, B, C$, cultures $\mathrm{A}, \mathrm{B}$, and $\mathrm{D}$ from sugar beets; $D$, culture A from sweet potato ; $E$, culture $\mathrm{C}$ from Mexican Red bean; $F$, culture from citrus; $G$, culture from strawberry. All except the culture from citrus $(F)$ were pathogenic to bean and cowpea seedlings.

the cultures from sweet potato and cowpea were only slightly larger than the limit established for Haigh's $\mathrm{C}$ group and are scarcely large enough to warrant classification in the $\mathrm{B}$ group in which Haigh gives the diameter of the sclerotia as about $200 \mu$. The culture of Haigh's A strain, with large sclerotia, according to the work of Hopkins, ${ }^{(5)}$ should be designated as Rhizoctonia lamellifera Small.

\section{EFFECT OF TEMPERATURE ON GROWTH OF MYCELIUM IN CULTURE}

Eight cultures of the fungus were grown at controlled temperatures ranging from $3^{\circ}$ to $40^{\circ} \mathrm{C}$. Large test tubes provided with a dam at the open end, made by heating the glass and indenting one side, were used in determining the rate of mycelial growth. Prune agar (15 cc) was placed in each tube and allowed to cool with the tube in a horizontal position, the dam preventing the escape of the melted agar. When solidified the agar extended the entire length of the tube $(20 \mathrm{~cm})$ and was 
uniform in depth. Each tube was inoculated near the dam at the open end with aerial mycelium from plate cultures, incubated 24 hours at room temperature, and then marked with a wax pencil to indicate the edge of the colony.

Three tubes of each culture were then placed in each incubator in a horizontal position and the amount of mycelial growth beyond the first

TABLE 1

Relation of Temperature to Rate of Mychital Growth of Cultures of RHIZOCTONIA Bataticola from Different Hosts

\begin{tabular}{|c|c|c|c|c|c|c|c|c|}
\hline \multirow[b]{2}{*}{ Temperature. ${ }^{\circ} \mathrm{C}$} & \multicolumn{8}{|c|}{ Average daily growth of mycelium, in $\mathrm{mm}$} \\
\hline & Beet A & Bean C & Cowpea & $\begin{array}{c}\text { Sweet } \\
\text { potato B }\end{array}$ & Begonia & Citrus & $\begin{array}{l}\text { Straw- } \\
\text { berry }\end{array}$ & Cotton \\
\hline $3 \ldots .$. & 0.0 & 0.0 & $\ldots \ldots .$. & 0.0 & 0.0 & 0.0 & 0.0 & 0.0 \\
\hline $8 \ldots \ldots \ldots \ldots \ldots \ldots \ldots$ & 0.0 & 0.0 & 0.9 & 0.0 & 0.0 & 0.0 & 0.0 & 0.0 \\
\hline $12 \ldots$ & 3.6 & 3.4 & 5.3 & 3.3 & 3.4 & 0.7 & 4.8 & 3.7 \\
\hline 16. & 11.0 & 10.6 & 13.3 & 11.9 & 13.0 & 4.4 & 12.5 & 13.2 \\
\hline 19 & 12.6 & 11.3 & 11.5 & 13.2 & 14.4 & 4.6 & 13.7 & 13.5 \\
\hline $22 \ldots \ldots \ldots \ldots \ldots \ldots \ldots \ldots \ldots \ldots \ldots \ldots \ldots \ldots \ldots$ & 15.6 & 11.2 & 16.5 & 14.9 & 16.3 & 7.5 & 17.3 & 17.3 \\
\hline $25 \ldots$ & 25.3 & 20.0 & 28.7 & 23.7 & 29.8 & 13.1 & 27.4 & 30.8 \\
\hline $28 \ldots$ & 27.4 & 21.0 & 29.1 & 25.8 & 29.0 & $14.8^{*}$ & 29.3 & 31.3 \\
\hline $31 \ldots$. & $\$ 1.0$ & 22.3 & 32.2 & 26.4 & 32.0 & 14.4 & 32.0 & \$S.S \\
\hline $34 \ldots \ldots \ldots \ldots \ldots$ & 28.8 & 26.4 & 37.8 & 26.0 & 30.0 & 6.5 & 30.3 & 32.5 \\
\hline 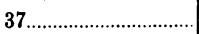 & 17.5 & 18.3 & 29.0 & 4.8 & 2.7 & 1.6 & 23.0 & 15.4 \\
\hline 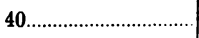 & 0.0 & 0.0 & 0.0 & 0.0 & 0.0 & 0.0 & 0.0 & 4.3 \\
\hline
\end{tabular}

* Figures in italics indicate the growth at the optimum temperature in culture.

wax pencil mark was measured daily until the mycelium had grown about 12 to $14 \mathrm{~cm}$. The daily rates of growth at each temperature were fairly uniform, but in most instances the maximum occurred on the first or second day. The average daily growth of each culture is recorded in table 1.

The results, summarized in table 1 , show that practically no growth occurred at $3^{\circ}$ or $8^{\circ} \mathrm{C}$ and very little at $12^{\circ}$, and that the optimum temperature was about $31^{\circ}$ for all except the cultures from bean and cowpea, which grew most rapidly at $34^{\circ}$, and the culture from citrus, which grew only about half as fast as the others and proved to be practically nonpathogenic. The culture from cotton was the only one to grow at $40^{\circ}$, and was the only one of these eight cultures found to cause infection at this temperature.

\section{METHOD OF TESTING PATHOGENICITY OF FUNGUS ON SEEDLINGS}

In testing the pathogenicity of the cultures, seeds of Mexican Red bean (Phasedrus vulgaris L.) and California Blackeye cowpea (Vigna sinensis L.), which had been surface-sterilized in mercuric chloride 1:1000, 


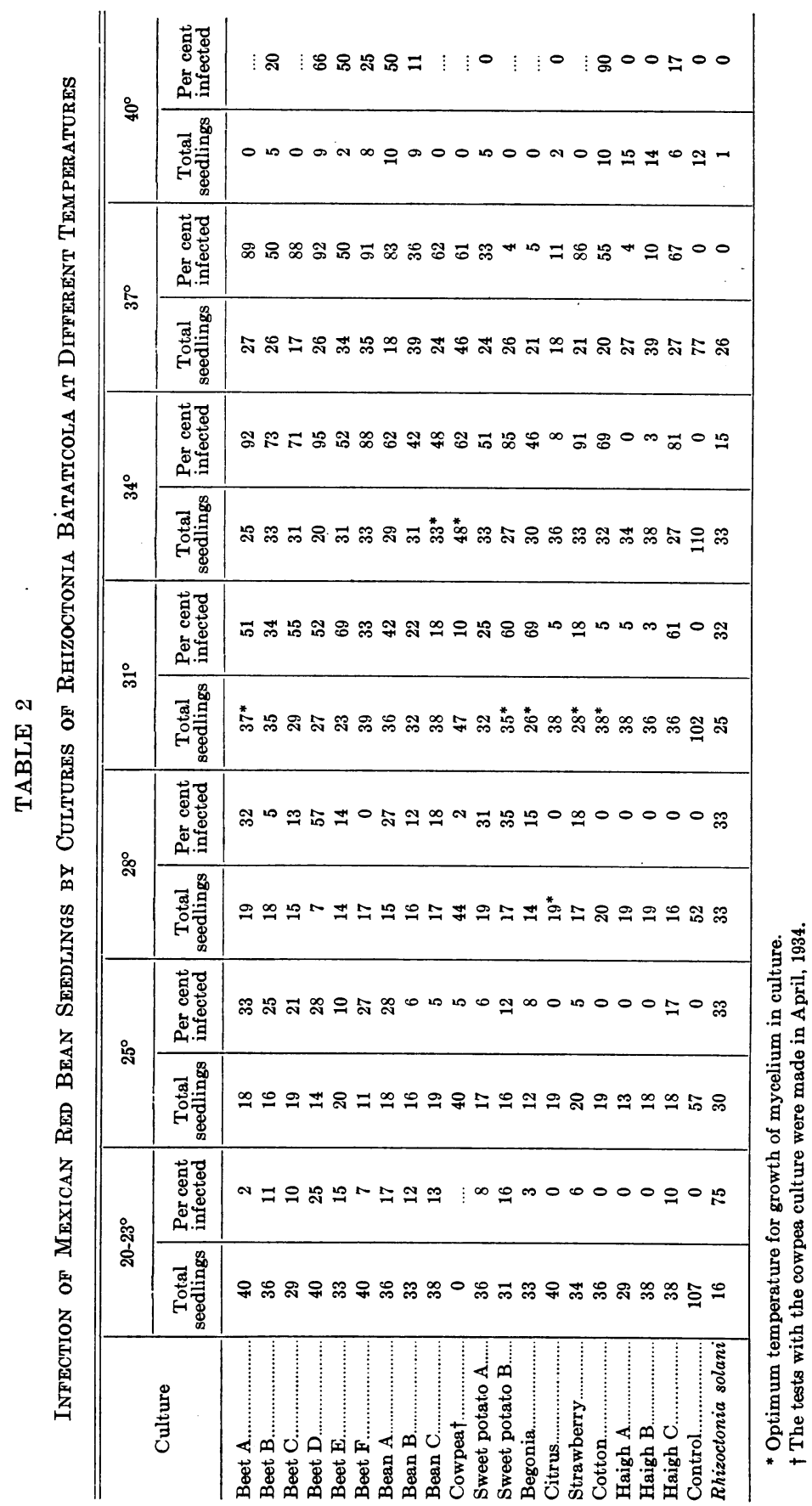


rinsed, and dried, were planted in moist sterilized sand with which shredded prune agar plate cultures of the fungus had been mixed. Paraffined cardboard drinking cups, $7 \mathrm{~cm}$ deep and $7 \mathrm{~cm}$ in diameter, were used as containers. Inoculum was used at the rate of one petri plate culture for two cups, and the moist sand with which the inoculum had been mixed was incubated 4 to 6 days at room temperature before it was placed in the cups. Ten seeds were planted in each cup. Two cups were planted with beans and two with cowpeas for each culture at each temperature. In addition, six cups with sterile prune agar as inoculum were used as controls at each temperature, all of which remained free from infection, and two with a culture of Rhizoctonia solani.

Preliminary tests showed that infection occurred most commonly on the cotyledons only, so that it was necessary, in examining the seedlings, to remove the seed coats in order to detect the lesions on the cotyledons. These lesions were at first circular dark-brown or black spots of various sizes (fig. $2 A, C, D$ ). Usually these lesions coalesced more or less (fig. $2 B$ ) and frequently the entire cotyledon was invaded and blackened (fig. $2 E, F$ ) and contained numerous sclerotia. The hypocotyl lesions were linear and blackened (fig. $2 A, C, F$ ). The identity of the fungus was proved by numerous reisolations from the cotyledon and hypocotyl lesions.

The composite results of two series of tests with beans are shown in table 2 , and two series of tests with cowpeas in table 3 . In the first series, the cups were planted and placed in the incubators on February 17, 1933 , and removed after 4 days. The temperatures used were $31^{\circ}, 34^{\circ}$, $37^{\circ}, 40^{\circ}$, and room temperature $\left(20-23^{\circ} \mathrm{C}\right)$. In the other series the cups were planted and placed in the incubators on April 11, 1933. The cowpeas, because of their rapid growth, were removed after 3 days and the beans after 6 days. The temperatures used were room temperature $\left(20^{\circ}\right.$ $\left.23^{\circ}\right), 25^{\circ}, 28^{\circ}, 31^{\circ}, 34^{\circ}, 37^{\circ}$, and $40^{\circ} \mathrm{C}$. The series at room temperatures were exposed to light during the day. The other temperatures were provided by incubators which were not lighted.

\section{INFECTION OF BEAN SEEDLINGS AT DIFFERENT TEMPERATURES}

The results summarized in table 2 show that high percentages of the bean seedlings were infected at $31^{\circ}, 34^{\circ}$, and $37^{\circ} \mathrm{C}$, and that considerable infection occurred at the other temperatures also. All of the cultures were distinctly pathogenic except the citrus and Haigh's A and $\mathrm{B}$, and these cultures differed markedly in other respects as well.

For the eight cultures previously tested for rate of growth at different temperatures, the highest percentage of infection occurred at or above 


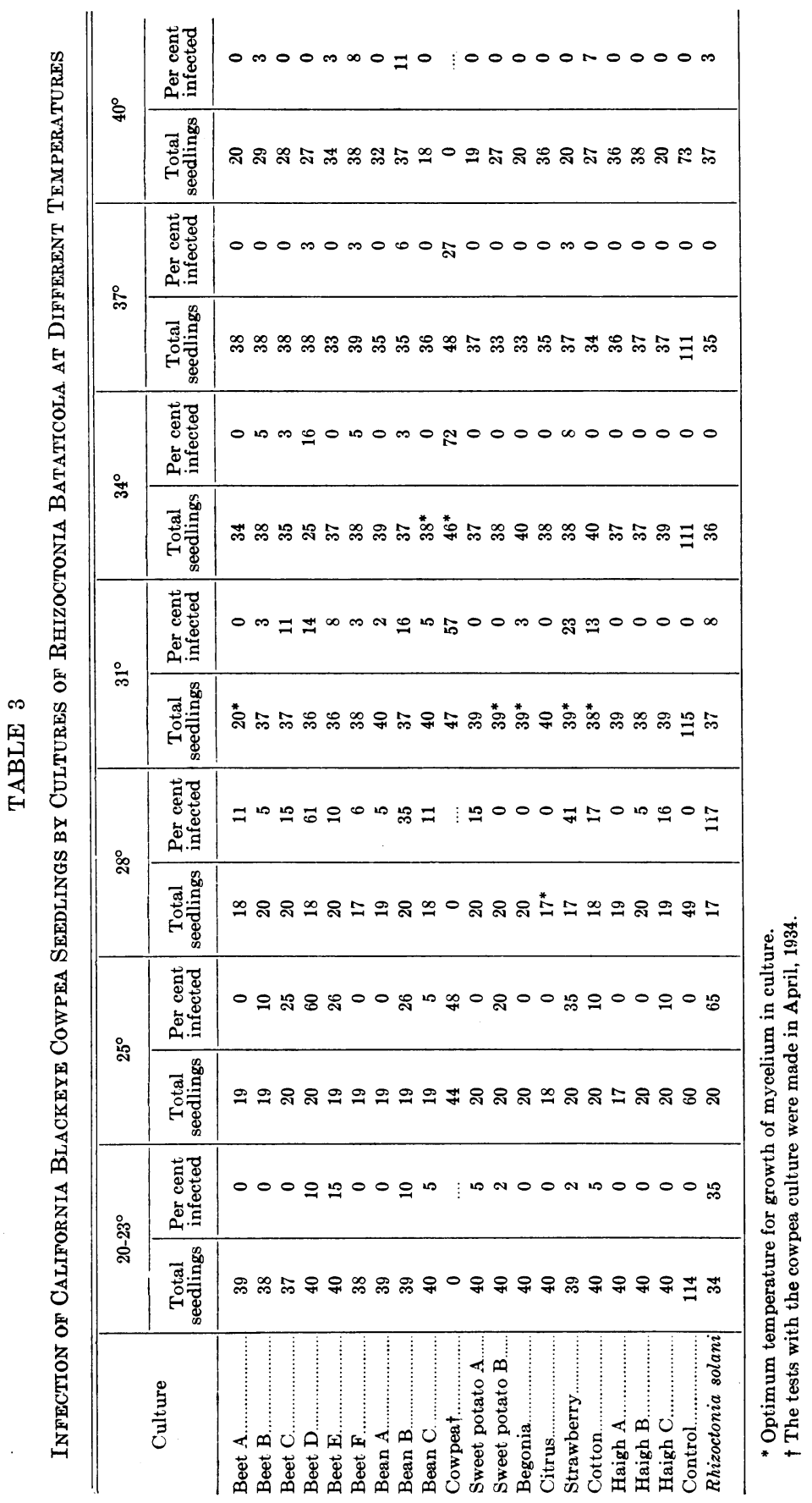


the optimum temperature for mycelial growth, but the culture from cotton, the only one to grow at $40^{\circ}$, was the only one of the eight to infect at this temperature. However, seven cultures not included in the rateof-growth tests were pathogenic at $40^{\circ}$. The fungus was reisolated from 424 of the bean seedlings. As was to be expected, Rhizoctonia solani was more pathogenic at the lower temperatures.

\section{INFECTION OF COWPEA SEEDLINGS AT DIFFERENT TEMPERATURES}

The cowpea seedlings, as shown in table 3 , were infected much less abundantly than the beans at the higher temperatures where the beans had proved most susceptible. In fact, there was little or no infection of the cowpeas at $34^{\circ}, 37^{\circ}$, and $40^{\circ} \mathrm{C}$, except with the culture from cowpea, while at $25^{\circ}$ and $28^{\circ}$ the cowpeas were only slightly less susceptible than the beans. With cowpeas, therefore, the maximum infection with all except the culture from cowpea occurred at temperatures $\left(25^{\circ}\right.$ and $\left.28^{\circ}\right)$ somewhat below the optimum for growth of the fungus in culture $\left(31^{\circ}\right.$ and $34^{\circ}$ ) but nevertheless within the range of temperatures favoring very rapid mycelial growth. The fungus was reisolated from 110 of the cowpea seedlings. Rhizoctonia solani was pathogenic to cowpea seedlings at the lower temperatures.

With the exception of the culture from begonia, the cultures which were pathogenic to the beans were also pathogenic to the cowpeas, although the $\mathrm{A}$ and $\mathrm{F}$ cultures from beet and the $\mathrm{A}$ culture from bean were less active. The culture from cowpea, which presumably is the same fungus which Mackie(8) has found very destructive in the Blackeye variety in the San Joaquin Valley when the plants are older, differed from all of the other cultures in being distinctly pathogenic at all temperatures tested $\left(25^{\circ}, 31^{\circ}, 34^{\circ}, 37^{\circ} \mathrm{C}\right)$.

\section{SEEDLING INFECTION COURTS}

Of a total of 932 infected bean seedlings, exclusive of those infected by the cowpea culture, 84 per cent were infected only in the cotyledons (fig. $2 B$ ) and but 9 per cent in the hypocotyl alone. Of the 182 infected cowpea seedlings, exclusive of those infected by the culture from cowpea, 82 per cent were infected only in the cotyledons and 13 per cent only in the hypocotyl. With the culture from cowpea there was much more hypocotyl and epicotyl infection in cowpea seedlings at the higher temperatures. With Rhizoctonia solani, 21 per cent of the infected beans and 50 per cent of the infected cowpeas were infected in the cotyledons.

The preponderance of cotyledon infection may explain why so much of the field infection observed by Kendrick ${ }^{(6)}$ was in the form of lesions 
at the cotyledonary node. In fact, in many of the bean seedlings the infection had already progressed apparently from the cotyledons into the upper part of the hypocotyl (fig. $2 E$ ).

In accord with Kendrick's field observations, no direct root infection was found. Consequently it would seem that seedling infection in the field would be most favored by the occurrence of high soil temperatures prior to the emergence of the cotyledons from the soil.

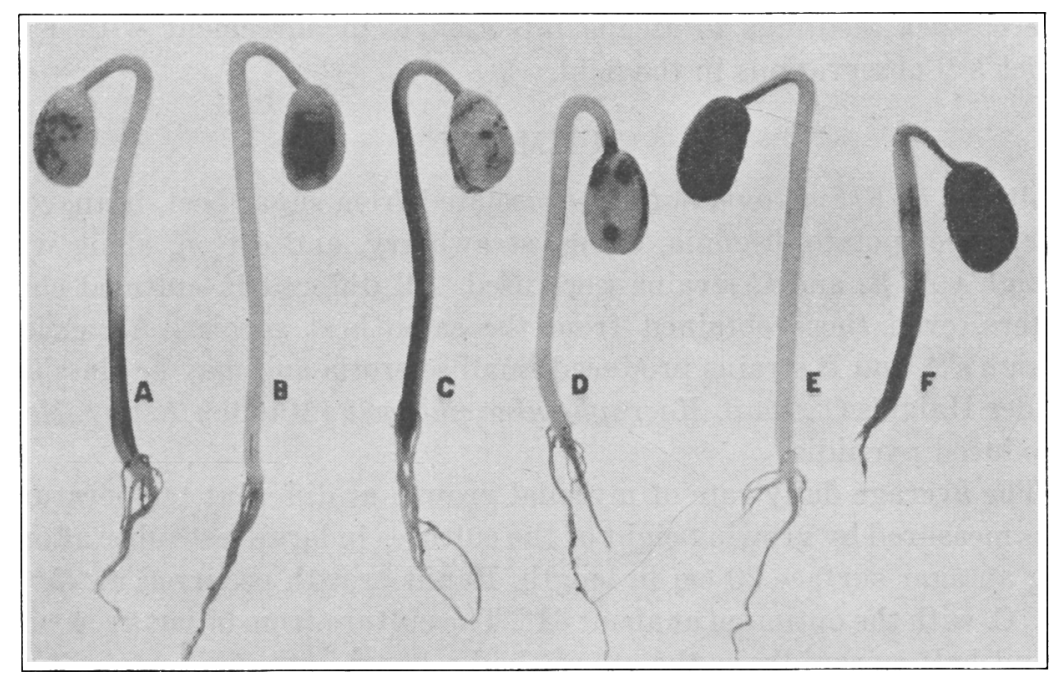

Fig. 2.-Cotyledon and hypocotyl infection of Mexican Red bean seedlings grown in sand inoculated with Rhizoctonia bataticola: $A$, small lesions on cotyledon and large lesion at base of hypocotyl; $B$, coalescence of cotyledon lesions; $C$, small lesions on cotyledon and lesion extending nearly the whole length of the hypocotyl; $D$, larger, circular lesions on cotyledon; $E$, cotyledons completely blackened and invasion extending into upper part of hypocotyl; $F$, cotyledons and lower and upper parts of hypocotyl infected.

\section{RATE OF GROWTH OF SEEDLINGS IN RELATION TO INFECTION}

It seems possible that the effect of different temperatures upon the rate of growth of the seedlings may explain why the cowpeas tended to escape infection at the higher temperatures. It was noted that at the higher temperatures some of the infected beans germinated but failed to emerge from the sand and at $40^{\circ} \mathrm{C}$ many failed to germinate, while the cowpeas germinated vigorously at all of the temperatures.

In a preliminary test of the effect of temperature on rapidity of germination and seedling growth it was found that the cowpea seedlings emerged more promptly than the beans at $28^{\circ}, 31^{\circ}, 34^{\circ}$, and $37^{\circ} \mathrm{C}$, and in average length of hypocotyl at 3 days exceeded the beans by $0.8 \mathrm{~cm}$ 
at $28^{\circ}, 1.4 \mathrm{~cm}$ at $31^{\circ}, 3.4 \mathrm{~cm}$ at $34^{\circ}$, and $4 \mathrm{~cm}$ at $37^{\circ}$. The cowpea hypocotyls averaged $3.6 \mathrm{~cm}$ at $28^{\circ}, 5.4 \mathrm{~cm}$ at $31^{\circ}, 6.7 \mathrm{~cm}$ at $34^{\circ}$, and $5.6 \mathrm{~cm}$ at $37^{\circ}$. Elongation of the bean hypocotyls was greatly retarded at $37^{\circ}$. Since most of the infection by all except the culture from cowpea took place in the cotyledons, it seems possible that the more rapid emergence and growth of the cowpea seedlings, by promptly removing the cotyledons from contact with the inoculum in the soil, may be a factor in enabling the seedlings to escape infection. The tendency of the cowpea seedlings to escape infection is in agreement with Kendrick's ${ }^{\left({ }^{(6)}\right.}$ observations in the field.

\section{SUMMARY}

Cultures of Rhizoctonia bataticola isolated from sugar beet, bean, cowpea, sweet potato, begonia, citrus, strawberry, and cotton, along with Haigh's A, B, and C strains were used. All differed in cultural characters, even those obtained from the same host species. All except Haigh's A and B strains produced small sclerotia and may be classified under Haigh's C group, Macrophomina phaseoli (Maubl.) Ashby. None produced pycnidia.

The average daily rate of mycelial growth at different temperatures was measured by growing eight of the cultures in large test tubes affording an agar surface $20 \mathrm{~cm}$ in length. Rapid growth occurred at $25^{\circ}$ to $34^{\circ} \mathrm{C}$, with the optimum at about $31^{\circ}$. The culture from citrus grew only about half as rapidly as the others, had a lower optimum temperature, and proved to be nonpathogenic.

In testing the pathogenicity of the cultures at different temperatures, Mexican Red bean and California Blackeye cowpea seeds were planted in moist inoculated sand in paraffined cardboard cups and germinated at different temperatures $\left(20-23^{\circ}, 25^{\circ}, 28^{\circ}, 31^{\circ}, 34^{\circ}, 37^{\circ}\right.$, and $\left.40^{\circ} \mathrm{C}\right)$.

High percentages of the bean seedlings were infected at $31^{\circ}, 34^{\circ}$, and $37^{\circ}$, and considerable infection occurred at all temperatures. All the cultures were pathogenic except the citrus and Haigh's A and B.

With the exception of the begonia culture, the cultures which were pathogenic to beans also were pathogenic to cowpeas, although some differences in degree were noted.

The culture from cowpea was distinctly the most pathogenic to cowpea seedlings, particularly at the higher temperatures.

The cowpea seedlings tended to escape infection with all except the culture from cowpea at $34^{\circ}, 37^{\circ}$, and $40^{\circ} \mathrm{C}$, but at $25^{\circ}$ and $28^{\circ}$ were nearly as susceptible as the beans.

Most of the infection of both beans and cowpeas occurred in the cotyledons. 
The relative freedom from infection of the cowpeas at high temperatures may possibly be attributed in part at least to their prompt and vigorous germination and more rapid hypocotyl elongation at high temperatures as compared with the beans.

Rhizoctonia solani was pathogenic to the beans and cowpeas at the lower temperatures, and infected the cotyledons to a considerable extent. 


\section{LITERATURE CITED}

1 Ashby, S. F.

1927. Macrophomina phaseoli (Maubl.) comb. nov. the pyenidial stage of Rhizoctonia bataticola (Taub.) Butl. Brit. Mycol. Soc. Trans. 12:141-147.

2 Brown, W.

1928. Studies in the genus Fusarium. VI. General description of strains together with a discussion of the principles at present adopted in the classification of Fusarium. Ann. Bot. (London) 42:285-304.

3 Coons, George Herbert.

1916. Factors involved in the growth and the pyenidium formation of Plenodomus fuscomaculans. Jour. Agr. Research 5:713-769.

4 Haigh, J. C.

1930. Macrophomina phascoli (Maubl.) Ashby and Rhizoctonia bataticola (Taub.) Butler. Ann. Roy. Bot. Gard. Peradeniya 11:213-249.

5 Hopkins, J. C. F.

1930. Macrophomina phaseoli (Maubl.) Ashby and Rhizoctonia bataticula (Taub.) Butler. Ann. Roy. Bot. Gard. Peradeniya 11:213-249.

5 Hopkins, J. C. F.

1933. Rhizoctonia lamellifera Small: a distinet species of the Rhizoctonia bataticola group of fungi. Rhodesia Sci. Assoc. Proc. 32:65-79.

6 KENDRICK, JAMES B.

1933. Seedling stem blight of field beans caused by Rhizoctonia bataticola at ligh temperatures. Phytopathology 23:949-963.

7 Lfonian, Leon H.

1924. A study of factors promoting pyenidium-formation in some Sphaeropsidales. Amer. Jour. Bot. 11:19-50.

8 MACKIE, W. W.

1932. A hitherto unreported disease of maize and beans. Phytopathology 22: $637-644$. 